\title{
The nation-state and the river: Spaces and times on Dutch rivers, 1795-1814
}

\author{
Cornelis Disco* \\ University of Twente, Science, Technology, Health and Policy Studies, P.O. Box 217, 7500 AE, Enschede, Netherlands
}

\section{A R T I C L E I N F O}

Article history:

Received 13 November 2007

Received in revised form 17 June 2008

Accepted 27 June 2008

Available online 9 July 2008

\section{Keywords:}

Rivers

State-formation

Flood control

Commons

Batavian Republic

\begin{abstract}
A B S T R A C T
Nothing indeed demonstrates more forcefully the extent to which Dutch water management corresponds to the nature and the needs of the Dutch people and their land, and how it has emerged there from in a natural fashion than the fact that the revolutionaries of 1795 , despite being so intoxicated by their unexpected victory and sudden power that they overturned everything ... nonetheless refrained from laying hands on institutions whose extreme antiquity would in those days have provided more of an excuse to abolish than to preserve them (J.W. Welcker, De Noorder-Lekdijk Bovendams en de doorsteking van den Zuider-Lekdijk bij Culemborg 1803-1813. Een bijdrage tot de geschiedenis van den Nederlandschen Waterstaat geschetst en met onuitgegeven stukken toegelicht ('s-Gravenhage: 1880), p. 2).
\end{abstract}

(c) 2008 Elsevier Ltd. All rights reserved.

\section{Introduction}

On the 13th of January, 1811, the officers of the Dike Board of the Northern Lek Dike beneath the Dam installed themselves in their headquarters at Jaarsveld near the middle of their $25 \mathrm{~km}$ long dike. Melting river ice and high water on the river had called them there - following venerable custom and according to the Dike Board's precise regulations. Prior to their arrival, they had already mustered their "dike-army," composed of at least one able-bodied male between the ages of 16 and 60 from every household of the dike-district, including servants and field-hands. The men came armed with hoes, shovels, horses and wagons to aid them in shoring up soggy dikes, to heighten them with clay embankments where the floodwaters threatened to overtop them and to stop the leaks and seepages that could insidiously flush away a dike's core and leave it ripe for collapse. At 1:00 am on January 15th, the officers noted a river stage of $563 / 4 \mathrm{in}$. below the so-called emergency level (i.e. the top of the dike). By 1:00 pm the same day the level had dropped to $593 / 4$ in. below emergency level, and by midnight to $691 / 4$ in. The officers were ready to call it quits and send the dike army home when they were apprised of a missive from the national intendant (requestmeester) for "bridges and roads." They were advised in no uncertain terms that once the dike-army had been mustered it could not be sent home again without express orders from the national Inspector of the Rivers.

\footnotetext{
* Tel.: +31 649915784 .

E-mail address: c.disco@utwente.nl.
}

The following day, January 16th, the intendant himself came to inspect the dikes, and was received by the officers of the dike board. ${ }^{1}$

This minor incident, turning on a mistaken presumption by the officers of the dike board that they still had discretionary authority over disbanding their own dike army, illustrates both the persistence of old attitudes and the new intransigence of the national state during the 18 years of French domination of the Netherlands between 1795 and 1813. This period in fact established the Netherlands as a unified nation-state, and for the first time subjected water management and flood control - which had always been a local or at best a provincial concern - to central state authority.

It was not an easy transition. There was resistance by local and regional water management authorities who were jealous of their ancient privileges. To this was added a sincere conviction at all levels that the robust local systems of drainage and flood control could only be tampered with at the risk of inviting catastrophe. At the same time, it was apparent to many that there was something seriously wrong with the rivers, and that it was getting worse. Floods along the river had become ever more frequent in the course of the 18th century, and the devastation they brought was ever more complete and increasingly intolerable.

On the one hand, this was due to the deterioration of the riverbeds and floodplains which rendered the rivers increasingly unable to drain off floodwaters and ice floes. This deterioration had two main causes. First, the 18th century reconstruction of the splitting-point of the Rhine just below the German border had changed

\footnotetext{
${ }^{1}$ F.A.R.A. Baron van Ittersum, De Lekdijk Benedendams en de IJsseldam. Geschiedenis van dit Hoogheemraadschap van af de vroegste tijden, tot in de tweede helft der negentiende eeuw (en voortgezet tot in de 20e eeuw), vol. 3, 1795-1905 (Utrecht: J. van Druten, 1907), p. 93.
} 
flows in the various Dutch distributaries, sometimes with deleterious effects. ${ }^{2}$ Second, increasing population pressure had encouraged the "domestication" of portions of the riverbed and the floodplains. This took the form of reclamation of shallows and islands in the actual riverbed, the use of the floodplains for agricultural purposes (including the building of low "summer dikes" and the planting of trees), strangling the river in a plethora of groynes intended to abet reclamation and to protect mainline levees, and finally the construction of brick factories and other buildings on the floodplains. All these practices impeded flows of water and ice. During high waters in the winter, ice floes could easily snag on the many obstacles in the floodplains, leading to the formation of ice dams, extremely high water and dike breaches. ${ }^{3}$

But in addition to the increased likelihood of flooding due to the deteriorating hydraulic efficiency of the rivers, the amount of damage wrought by a typical winter flood had also increased over time. This was due in the first place simply to the increased population and investments in land and property in the communities lining the river. There was simply more to lose. But increased costs of flooding were also the result of secular processes of oxidation and soil subsidence due to increasingly effective drainage and the incorporation of the lowest lying parcels into the agrarian polder system. ${ }^{4}$ This reduction of the level of the lands behind the river dikes was aggravated by a complementary rise in the level of especially the floodplains due to silt deposits from the river. The two processes in tandem produced a secular increase in the difference between polder levels and the levels of the rivers at flood stages. For example, the difference in the level between the Lek in flood at Schoonhoven and the lowest lying part of Holland near Rotterdam amounted to nearly 20 meters by 1800 .

In any case there were a few voices, chiefly in the newly victorious Patriot camp, that ascribed the recurrent winter floods to the lack of a strong central authority able to prevent the spoiling of the flood plains by riparian farmers and landowners who put their private interests before the common good. In this article, I want to examine how these Patriot reformers and their new centralist state acted on this belief, and how the new state engineers managed to insinuate themselves into the venerable local practices of flood control on the rivers and thereby to lay a foundation for the multi-tiered structure of water governance that enabled, and still enables, the Dutch to prevail against the rivers and the sea - at least most of the time.

Between 1581 and 1795, the Netherlands was more like a loose federation of provinces than a nation-state. Its name, the "Republic of the Seventeen United Netherlands," suggests as much. Power was wielded chiefly by the seven Provincial Estates which deferred to the Estates General in The Hague only in matters of war and diplomacy. In 1795, this loose-jointed state was overthrown by Dutch "Patriot" revolutionaries. They were backed up by French Revolutionary troops who had taken advantage of frozen rivers

\footnotetext{
2 Anneke Driessen, Watersnood tussen Maas en Waal: overstromingsrampen in het rivierengebied tussen 1780 en 1810 (Zutphen: Walburg Pers, 1994), p. 31.

${ }^{3}$ Toon Bosch, Om de macht over het water. De nationale waterstaatsdienst tussen staat en samenleving 1798-1849 (Zaltbommel: Europese bibliotheek, 2000), pp. 22-23. Bosch's book provides an essential framework for anyone studying the first halfcentury of nationalized water management in the Netherlands, and I am greatly indebted to it for providing an overview and for clues on where to look in analyzing the Rijkswaterstaat's integration into local arrangements for water management. See also Alex van Heezik, Strijd om de rivieren. 200 jaar rivierenbeleid in Nederland (Den Haag/Haarlem: Rijkswaterstaat, 2006), Driessen.

4 Gerard van de Ven, ed., Man-made lowlands: history of water management and land reclamation in the Netherlands (Utrecht: Matrijs, 1993), G.J. Borger and J. Bruines, Binnenwaeters gewelt. 450 jaar boezembeheer in Hollands Noorderkwartier (Edam: Hoogheemraadschap van uitwaterende sluizen in Hollands Noorderkwartier; stichting uitgeverij Noord-Holland, 1994), Petra J.E.M. van Dam, "Ecological Challenges, Technological Innovations. The Modernization of Sluice Building in Holland 1300-1600," Technology and Culture 43, no. 3 (2002).
}

to march unhindered into the heart of the Netherlands. The new "Batavian" state was heir to the centralism that pervaded both France's absolutist and revolutionary traditions. In the course of the next half-century, the institutions of this centralized state persisting past the French occupation itself - increasingly challenged the old provincial and local hegemony over the rivers.

Under the Republic, water management was locally organized: drainage and flood control was managed by several thousand water boards. These had a tradition of fierce independence, having become accountable to their respective Provincial Estates only since the 1730s. In the course of the 18th century, a number of enlightened spirits began to argue that this fragmented water management made it impossible to deal with a number of pressing problems. Chief among these was the chronic flooding of the lands along the large rivers that coursed through the country: the Rhine and its distributaries, the Meuse and the Scheldt. ${ }^{5}$ A special concern, especially for the inhabitants of the wealthy maritime province of Holland, was the questionable state of the river dikes (levees) along the north shore of the Lek River. Breaches in these dikes would not only affect the immediate riparian populations but also those at a great distance from the river. The very heart of the country would be flooded, and unimaginable suffering and economic devastation would ensue. The diagnosis made by the leading lights of the day was clear enough: the dikes - especially those along the northern shore of the Lek - had to be improved, and the rivers and their beddings had to be re-engineered to enable them to carry off the upstream floodwaters and ice floes before they could form ice dams. ${ }^{6}$ The problem, however, was how to coordinate this as a national project given the vested interests of local and provincial elites who rather understandably - were interested above all in their own safety and political autonomy.

The quandary faced by the new centralized state, first under patriot and French rule and after 1814 under the House of Orange, was how to frame a national level of water policy and water control systems without compromising the quality and proven effectiveness of the dense fabric of local and provincial water management. On the one hand, it was impossible to simply replace these fine-grained local systems of drainage and flood control by uniform national systems. On the other hand, it would not do to let vested local and provincial interests continue to paralyze national projects for improvement of the rivers. The nationalization of river management seemed to many the only possibility for reducing the chances of disastrous flooding across the board, and especially for countering the threat that hung over the provinces of Utrecht and Holland. ${ }^{7}$

Most descriptions of the evolution of Dutch water management and flood control between 1795 and the 1850s tend to emphasize

\footnotetext{
${ }^{5}$ A "distributary" is a river branch that does not return to the main river. Distributaries are very common features of river deltas.

${ }^{6}$ This diagnosis had been made and publicized as early as $1740 \mathrm{bij}$ the surveyor of the wealthy and influential water board of Rijnland, Melchior Bolstra. Rijnland was the driving force behind the development of the Waterstaat Service of the Province of Holland which was the precursor of the national Waterstaat. Rijnland supplied the personnel, the expertise, the maps and the political clout for the first Provincial Waterstaat which itself prepared the ground for the concerted attack on the rivers and in particular the calamitous Northern Lek Dike. Paul van den Brink, "Rijnland en de Rivieren. Inrichting en vormgeving van de Hollandse rivierzorg in de achttiende eeuw," Tijdschrift voor Waterstaatsgeschiedenis 12 (2003). See also Paul van den Brink In een opslag van het oog. De Hollandse rivierkartografie en waterstaatszorg in opkomst 1725-1754 (Alphen a/d Rijn: Canaletto/Repro Holland, 1998). for the important role of map making in framing river policy in the 18th and 19th centuries. For the history of map-making by the Rijkswaterstaat see Hubert Charles Toussaint, Uitgemeten en uitgetekend: de geschiedenis van de Algemene Dienst van de Rijkswaterstaat (The Hague: Rijkswaterstaat, 1998).

7 Although floods in fact occurred most frequently in agricultural regions of the provinces of Gelderland and in Brabant, a major flood in the low-lying and heavily urbanized provinces of Utrecht or Holland could be expected to be much more extensive and immeasurably more destructive.
} 

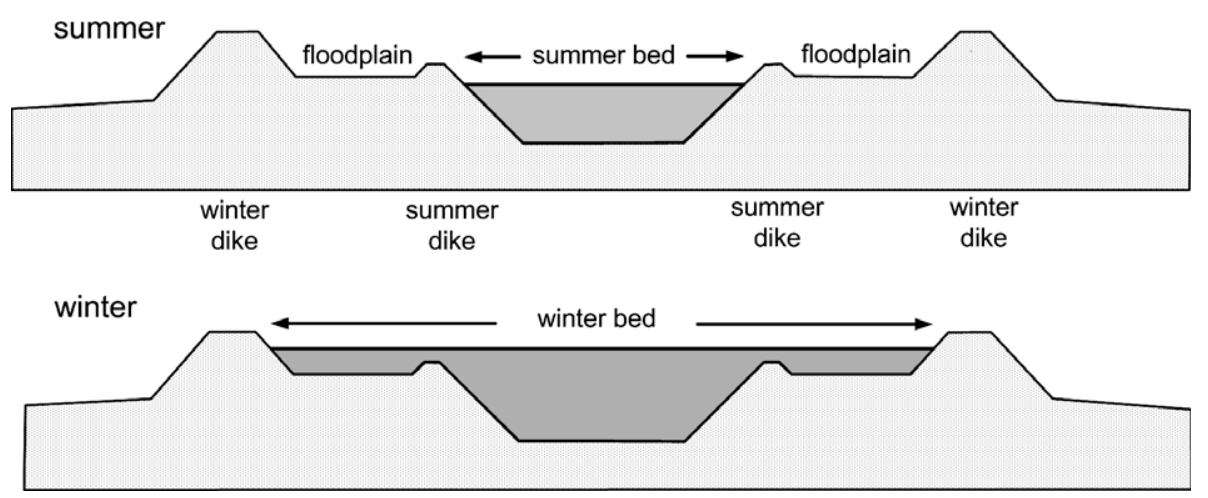

Fig. 1. Spaces and times on rivers.

the numerous plans for river improvement and flood control that were floated but not implemented during this period. ${ }^{8}$ Indeed, it took until 1850 before a coherent, authoritative and realistic plan could be put forth (by the state engineers J.H. Ferrand and L.J.A. van der Kun). Prior to that time, the Rijkswaterstaat (the new national public works agency founded in 1798) lacked a convincing and coherent engineering strategy, let alone the political backing, to actually initiate any kind of ambitious centrally coordinated river engineering projects. However, I want to argue here that despite the lack of consensus on river-engineering and the paucity of actual improvements to the condition of the river beds or to the morphology of the river system between 1795 and 1850, the national government - embodied in the nascent Rijkswaterstaat - did succeed in establishing an institutionalized beachhead on the rivers. It accomplished this on the basis of its cosmopolitan expertise, its national organizational scale, and especially its position as mediator among conflicting local and regional interests.

However, this beachhead was not and could not be based on the simple displacement of local powers. Instead, it depended on the exploitation of various niches in the existing structure of riverine governance. The Rijkswaterstaat succeeded in establishing a measure of control both over specific places in the river and over specific times or occurrences. This could only be sustained in the long run, especially after the resurgence of provincial powers after the end of French domination in 1813, if local and regional parties became convinced that such interventions actually improved the ability to manage or prevent floods. The resulting nested structures of river management and flood control were instrumental in preparing the ground for the radical river improvements of the second half of the 19 th century.

\section{Spaces and times on the river}

During the "Batavian-French period" lasting from 1795 to 1814 , the Rijkswaterstaat made inroads on the Dutch rivers by striving for mastery over specific places and times. This gave the agency a measure of national control, without seriously compromising the crucial role of existing local drainage and flood control arrangements. The resulting distribution of rights and responsibilities can be mapped onto the complex cross-sectional morphology of diked-in rivers. Fig. 1 shows a typical diked-in river in the Dutch lowlands. Four different zones can be discerned: (1) the river in the so-called summer bed, (2) the floodplains, which at high river stages, are part of the "winter bed," (3) the

\footnotetext{
${ }^{8}$ Ven, ed, Anton Bosch, "Naar eenheid en eenvoud. De oprichting en ontwikkeling van de Rijkswaterstaat 1798-1850." Tijdschrift voor Waterstaatsgeschiedenis 7, no. 2 (1998), Toon Bosch and Willem van der Ham, Twee Eeuwen Rijkswaterstaat. 17981998. (Zaltbommel: Europese Bibliotheek, 1998).
}

dikes, and (4) the lands behind the dikes. Moreover, the figure shows two different "times," first, the river under normal conditions and second, the river at high stages. In the Netherlands, the first situation is typical of the summer half-year and the second of the winter half-year, hence the concepts of "summer" and "winter" bed. The river's morphology is different between the first and the second "times." At high stages, the floodplains and summer dikes become part of the riverbed. Also, at high stages the dikes are waterlogged, under pressure from river water, and susceptible to breaching. Both the different zones and the different times present different kinds of opportunities for the imposition of national authority and hence map different combinations of local and national governance.

The lands behind the dikes were and are a mixture of private and public property: farms and homes, but also roads, public buildings and other infrastructure. The land and objects were under the purview of towns, villages councils and provinces, and after 1795 of the nation state as well. Holders of private property in the vicinity of the dikes were compulsory members of the local dike board, being burdened with the physical maintenance of a particular section of dike or its equivalent in taxes - under pain of fines and imprisonment. It should be noted that their exertions and sacrifices often benefited property holders at very great distances from the river. The flat lands through which the middle and lower reaches of these rivers coursed offered little resistance to the propagation of floods, and some dikes protected lands at a distance of nearly $100 \mathrm{~km}$ from the rivers themselves. As noted, the most sensitive site was the Northern Lek Dike, divided between two distinct dike boards, which protected much of the provinces of Holland and Utrecht. The situation here was extra dangerous, not only because of the questionable state of the dike's foundations, but also because the lands at some distance from the dike were actually much lower than those immediately behind the dike. In fact, when the river was in flood, its waters were almost 20 meters higher than the lowest portions of the countryside. In the event of a dike rupture here, the floodwaters would rush into these depressions with terrifying speed, taking everything with them that stood in the way.

The second zone, the actual dikes, which were designed to confine the river's flow between sharply defined boundaries even at the highest river stages, was built, owned and managed in common by the property owners whose lands were immediately or nearly contiguous. Organized within the legal framework of the dike board, these landholders contributed to the maintenance of the dikes either in natura or, increasingly in the course of the 19th century, in the form of specific dike taxes. The dikes were neither public property in the sense that they were managed by municipal, provincial or national governments, nor were they strictly speaking private property, in the sense that individual owners could use and abuse them as they saw fit. Rather, as Arne Kaijser argued, they 
were a kind of commons. ${ }^{9}$ From this perspective, the water or dike boards were institutions that organized the "commoners" for the purpose of maintaining their collectively owned dikes. This said, dikes were not a classic commons in the sense of a resource which was actually used by villagers as members of a water board, and which could be degraded by such use to eventually produce "tragic" outcomes. ${ }^{10}$ Dikes were "used" to turn high water, to be sure, but this was not used by the inhabitants themselves; wear and tear on the dikes depended on the vagaries of the river and the climate, as well as on the quality of dike maintenance. What was held in common, actually, was the collective burden of keeping the dikes in good condition, i.e. routine maintenance, preventing abuse, and ensuring that such damage as was done to dikes by high water and other causes was repaired as soon as possible. The major socio-political problem, then, was not to regulate the actual use of the dikes as in the case of "common pool resources," but to ensure equity in the burden of upkeep. ${ }^{11}$ This was accomplished by apportioning a portion of the water board's total dike-length to the various landholders in proportion to the size of their landholdings. And because some sections of dike were more susceptible to damage or harder to maintain than others, each landholder was apportioned sections in both "easy" and "hard" reaches of the dike. ${ }^{12}$ It goes without saying that ensuring and maintaining justice, especially in the eyes of the "dikeburdened" themselves, demanded fine negotiating skills and periodic adjustments and revisions in the allotment of dike parcels. Many local dike-regulations called for such periodic readjustments at intervals varying from a mere 6 years in some river districts to 33 years in West Friesland. ${ }^{13}$

Between the actual river and the dike existed floodplains of varying width, which with a little help from low "summer-dikes" fring-

\footnotetext{
${ }^{9}$ Arne Kaijser, "System Building from Below. Institutional Change in Dutch Water Control Systems," Technology and Culture 43, no. 3 (2002).

10 The seminal essay on such classic commons including the reasons why they inevitably had "tragic" outcomes is Garrett Hardin, "The Tragedy of the Commons.," Science 162 (1968). Hardin's somber view of commons has since been refuted by, among others, Eline Ostrom. See Elinor Ostrom, "Collective Action and the Tragedy of the Commons," in Managing the Commons, ed. Garrett Hardin and John Baden (San Francisco: 1977), Elinor Ostrom et al., eds., The Drama of the Commons (Washington DC: National Academy Press, 2002). However, there were also the uses of the dikes by the commoners which involved them in the logic of Hardin's tragedy of "common pool resources," (as Ostrom later characterized them). For example, allowing their pigs and geese to graze on the dikes, driving horses and carriages on their outer flanks, or allowing trees to grow in them could all affect the integrity of the dikes and degrade their usefulness as flood-defenses. Such practices were in fact frequently forbidden on pain of fines or even imprisonment by the regulations of many dike boards.

11 "Common pool resources" are defined by Elinor Ostrom as commonly owned resources, i.e. resources freely accessible to members of some community and thus devoid of individual property rights, which are also degraded or consumed by use. These are the kinds of commons which Garret Hardin described as being susceptible to "tragedy."

12 A.A. Beekman, Het dijk- en waterschapsrecht in Nederland vóór 1795, 2 vols. (The Hague: Martinus Nijhoff, 1905), 494, pp. 1538-1539.

13 A.A. Beekman, Het dijk- en waterschapsrecht in Nederland vóór 1795, 2 vols. (The Hague: Martinus Nijhoff, 1905), 494, pp. 1539-1542. This periodic revision of the dike-registers (dijkcedullen) was necessary in view of the constantly changing conditions of the dikes and the changing property qualifications of the villagers. The pursuit of equity in this division of dike maintenance (verhoefslaging), which often involved burdening a given property with an "easy" and a "difficult" stretch of dike, further increased the already extreme fragmentation of dike sections. Some indication is provided by the dike-registers of the village of Hellouw on the Waal. This village was responsible for some $3.5 \mathrm{~km}$ of mainline dikes along the Waal. Up to 1779 maintenance duties were reapportioned among the village property owners every 6 years; thereafter every 10-14 years. The $3.5 \mathrm{~km}$ of dikes was divided up into some 312 parcels, giving an average length of about $11 \mathrm{~m}$. Parcels were measured in Gelderland Rods ( $=3.8 \mathrm{~m}$ or 16 Gelderland feet). Only three parcels exceeded 20 rods, the biggest being 30 rods. Most parcels were one or two rods long. The smallest parcel was only 1 foot, 7 and 2/3(!) in. long. Besides the frequent revision and fragmentation of dike duties, the extreme precision (at least on paper) testifies to the high value placed on an equitable distribution of dike duties. Dijkcedullen van Hellouw 17731833, Polderdistrict Tielerwaard v.Idd 283 Rijks Archief Arnhem. www.hogenda.nl/ Docs/Attachment.aspx?ID=\%7Bf9f5f104-2a03-457e-adae-2d6a1aba57fb\%7D.
}

ing the river's summer bed, could be expected to remain dry throughout the summer growing season. These floodplains, like the lands behind the dikes, also consisted of private holdings. The extremely fertile lands were generally used for growing crops, but brick factories, farm buildings and even castles (e.g. Doorwerth Castle dating from 1280) had been and continued to be built on the higher portions. The floodplains were politically an extension of the riparian lands behind the dikes but inasmuch as they were subject to flooding in the winter could only be depended on for part of the year, generally from May to October. At higher river stages the floodplains actually became part of the riverbed, and their condition partly determined the river's capacity to discharge water and ice. Though seasonal crop-growing had little impact because there was at most only short stubble left on the fields after the harvest, the cultivation of trees and the construction of high summer dikes and buildings structurally impeded the river's ability to discharge water at high stages. Hence, floods made manifest the latent conflict of interest between the local users of the floodplains and the upstream riparian populations. The more intensive the use of the floodplains at any point along the river, the less effective the river became in discharging water and ice at that point, and the higher the river stages upstream of that point would become. The tenacity of the problem lay in the disjunction between those who profited from what farsighted commentators called the "spoiling" of the riverbeds and those others who might suffer when high water and ice choked the constricted river. There was, in other words, no short-term incentive not to "spoil" the local floodplains and every consideration of self-interest to do so. Also, exploiting the floodplains delivered constant benefits while it exacted only occasional costs.

The "minimal" river, the actual shipping channel indicated in Fig. 1 as the "summer bed," was that portion of the riverbed that was permanently inundated by the river's flow - even at the lowest river stages. It obviously had no agricultural relevance for the local riparians, though it could supply them with fish and, more importantly, with reclaimed land which could be added to private floodplain property and planted with crops or trees. Though under certain conditions riparian populations had rights to both, they could have no property in the river itself. Needless to say, both permanent fishing nets and the reclamation of land from the summer channel were hardly a boon to navigation or to the river's capacity to discharge water. Again, here was a latent conflict of interest between riparian landowners with an interest in "privatizing" portions of the public domain contiguous to their properties and more distant (and national) parties who wanted to optimize that public domain for the purposes of navigability and flood control. This tension had already been manifest in provincial ordinances regulating private encroachments on the river during the Republic. These were codified in Gelderland by 1715 , and specified that only reclamations directly adjoining the shore could be privatized. Groynes could not extend more than one-third of the way across the river. However, these regulations were hardly enforced in actual practice, and the riverbeds continued to be further constricted. ${ }^{14}$ During the "French period", the nation-state assumed the burden of superintendence of local river usage, ultimately codified in the "River Law" of 1806 (see Fig. 3).

But this placid, if heterogeneous, topology could be overturned by times of high water. At such times, new threats and interests emerged which provided a different basis for grafting local to national interests. What was river (and river bed) and what was not, depended on the river's stage at any given moment. The summer bed defined the river only at its very lowest stages. When heavy rains, ice dams, and constrictions and obstacles in the riverbed caused the waters to rise, the river covered the floodplains and crept up against the winter dikes. The privatized floodplains now became

\footnotetext{
14 Driessen, 61-62.
} 
part of the river bedding, and could be redefined as possibly troublesome hydraulic surfaces. The swollen river now became a common threat to all the riparian farms, villages and towns along its length. It was clearly in the general interest of these inhabitants and their governments that the dikes should everywhere be as strong as possible, and that the river bed itself should be as efficient as possible in discharging the flow. Similar considerations applied to the breaking up of ice jams, at least for river stretches upstream of the dams. In a sense, then, the river in flood was a kind of inverse commons: not a shared resource, but rather a shared threat which made it advantageous for the various stakeholders to act in concert to improve their collective chances of escaping tragedy.

However, there was also a perverse element involved in this game inasmuch as a dike breach at any location tended to lower water levels in the river, and was perceived to reduce chances for dike breaches at other locations, both upstream and downstream. The widespread concern for the integrity of the Northern Lek Dike, for example, made artificial floodways that drew water away from the dike into the so-called diversions, a seductive option for some. A major question facing the protagonists of a national presence on the rivers was to what extent national policy could facilitate the creation of artificial diversions which would sacrifice smaller or more sparsely settled lands to save larger and more urbanized lands from flooding.

\section{The nation-state on the rivers}

\subsection{The Unitarist State, $1795-1801$}

The Unitarist Constitution of 1798, which established the Batavian Republic, made only the most fleeting reference to water management, avowing that the new state would exercise a mandate for toezicht, i.e. superintendence, of the "dikes, roads and waters". ${ }^{15}$ Despite the brevity of the allusion, it was clear that in this sphere federalism, i.e. a state founded on an alliance among largely autonomous provinces, had had its day. The new policy in the area of water management was detailed in Instructions for the "Agent for Internal Affairs and Supervision of the Dikes, Roads and Waters of the Batavian Republic" passed by the Representative Assembly in October $1799 .{ }^{16}$ The agent's Instructions stipulated that he was thenceforth charged with "superintendence of private works and those not turning rivers and seas, in addition to those turning rivers and seas." However, the maintenance of all works remained the responsibility of the "owners or the dike and polder boards." carry out this ambiguous program, a "chief commissar-inspector" was appointed, along with a staff of fourteen "commissars-inspectors." 18 The latter functionaries were stationed in the various "departments" into which the Batavian Republic was divided, and were responsible for inspecting the water boards and for seeing to the execution of national public works policies.

Though the precise organizational and political arrangements would change frequently in the years to follow, the Instructions of 1799 established a national organization in the domain of water

\footnotetext{
15 Grondwet van 1798, Titul IV, Van het Uitvoerend Bewind, Lid XCII.

16 This agent (i.e. minister) was one of eight appointed by the "Executive Body" (the Dutch version of the French Directoire) to implement its new policies. Drafting watertight instructions seems to have been no sinecure. A committee was appointed in August 1798, but it took more than a year and a number of revisions before the text was approved by parliament on October 31, 1799. Joan Roëll, Historisch-staatsregtelijk onderzoek naar het algemeen en het bijzonder bestuur van den Waterstaat in Nederland van 1795-1848 (Utrecht: J. de Kruyff, 1866), pp. 45-53.

17 Welcker, p. 5. "Private" here refers to non-state ownership, i.e. also the property held in common by private landowners, like most of the dikes along the rivers.

${ }^{18}$ Christiaan Brunings, eminent surveyor and former chief engineer of the large and prosperous Rijnland Water Board, was appointed as the first chief commisarinspector.
}

management and public works which turned out to be surprisingly robust. ${ }^{19}$ This organization not only survived the new constitution of 1801, which restored provincial/departmental superintendence over the water boards, but even the fall of Napoleon and the establishment of the Kingdom of the Netherlands in 1814. Throughout all these changes its personnel also remained remarkably stable, with experienced surveyors and waterworks engineers like Christiaan Brunings, Jan Blanken, Adrianus F. Goudriaan and Frederik W. Conrad setting the tone for many years.

How did the new organization, a creature of the centralizing ideology of the revolutionary Batavian Republic, acquit itself of its novel responsibilities? How was national "superintendence" over "private" works realized in practice? In particular, what spaces and what times were seized upon to establish a national presence on the rivers?

There was little the nation-state could do in the private-public space behind the dikes. This was the domain of village councils, private landholdings and dike-boards. The dikes themselves, as "works to turn the water," were subject by virtue of the Instructions to "superintendence" by the commissars-inspectors. Twice-yearly inspections were mandated, and water boards could be called to account if their dikes were substandard or poorly maintained. However, from the perspective of the local dike boards this was not really a novel form of discipline, but simply a continuation of the superintendance formerly exercised by the provincial estates. It may well have made a difference, of course, that inspections were now carried out by a more distant national, rather than a (likely more "incestuous") provincial, authority. ${ }^{20}$ The third space, the floodplains, was somewhat more amenable to national control than the lands behind the dikes inasmuch as it could be said to contain works and structures which affected the hydraulic performance of the river. Still, it was a space of private landholdings and occasional common pastures which had not suffered much in the way of provincial regulation under the Republic. The Instructions did seem to provide a new legal basis for national interference in this domain, though nothing was as yet specifically spelled out. Finally, there was the navigational channel. The big rivers were all navigable, and this was a clear mandate for the nation-state - as it had been for the provinces. Navigation clearly predicated the subjection of local interests (in matters such as fishing, ferries, bridges, land reclamation and harbors) to regional, national and even international interests in the maintenance of a continuous and unimpeded waterway. That this also extended to the engineering of the river bed for purposes of flood control seemed a logical but by no means necessary extension of this principle. There were legal precedents in the sense that the former provinces had claimed jurisdiction over the river beds - as well as over a continuous towpath along the banks. ${ }^{21}$ In a sense, then, the actual water in the river, as well as the summer

\footnotetext{
19 Bosch, Om de macht over het water. De nationale waterstaatsdienst tussen staat en samenleving 1798-1849, pp. 109-112.

20 The condition of the dikes was in any case a matter of concern to the Patriot government from its inception. A circular letter from the Committee for the General Welfare of the Provisional Representatives of the People of Holland to all the dike boards dated August 5, 1795 “'earnestly warned them (the dike boards, CD) and if necessary commanded them' before the coming winter to repair all damage incurred to dikes and sluices over the past season, in order to prevent disasters." cited in Ittersum, p. 31.

21 Van Ittersum cites an ordinance dated 1553 in which priority in the use of the river banks is granted to transient users rather than to riparian residents. It is stated that "inasmuch as the use of all banks and shores of streams are common and public, in order that they may be used by anyone to facilitate shipping on the river." Edicts of Maximillian of Burgundy "Regarding the conservation of the towpath along the River Lek." Cited in Ittersum, p. 51. The point was that the emperor, and later the Provincial Estates, regarded it as their responsibility to ensure that the towpath remained free and accessible, which of course encroached on the free use of the river banks by private owners of riparian property. See also Jan Godfried Adriaan van Zijst, De Nederlandse Strafwetgeving ter Bescherming van Dijken en Rivieren (Utrecht: J. Greven, 1867)
} 
bed, had always been a kind of commons, held in trust by emperors and princes, provincial estates and now by the Agent in the name of the Batavian Republic and its people.

Hence, while there were clearly spaces on the river which the new Rijkswaterstaat could exploit in pursuit of more effective flood control, there were just as obviously spaces from which it was all but excluded. However, this static topology of influence could be dramatically transformed by episodes of high water on the rivers. Times of high river stages or times when the river was threatened by ice dams afforded special opportunities for nationalizing superintendence. Although the "French period" was a turbulent episode in Dutch history, nature was hardly impressed, and as always the advent of every winter brought the renewed threat of high river stages, ice dams, dike breaches and flooding. Though all the dike boards had venerable protocols for dealing with extraordinarily high river stages or the breakup of ice on the river, as can be gleaned from the story at the outset of this paper, the Agent and his corps of "commissar-inspectors" felt a growing sense of their own national responsibility at the outset of each new and threatening winter. This impulse toward a new nationalized order on the Dutch rivers drew inspiration not only from the Batavian constitution, but also from the near-failure of the northern Lek dikes in $1795 .^{22}$ It became a concerted effort after a series of dike breaches once again caused extensive flooding along all the major rivers in the winter of 1799-1800.

The first sally by the new state into governance of the rivers flowed forth quite directly from the prerogatives of superintendence over dikes and other works as set out in the Instructions of 1799. On January 9th, 1800, the Agent for the Department of Supervision over the Condition of the Dikes, Roads and Waters submitted a request to the Executive Council that in view of the "terrible events" of the previous year and "fearsome disasters" possibly to come, first, experts be sent, as in the previous year, to inspect the emergency stores prepared by the dike boards for the coming winter and "in case of emergencies to keep an eye on the work of the dike boards", and second, Lieutenant-Colonel-Inspector C.R.T. Krayenhoff be dispatched to the town of Gorinchem "in times of need" to keep the government "informed of the condition of the threatened lands." ${ }^{23}$ Note that the state is here no longer merely "supervising" the local care of dikes and sluices on a routine basis, but seizing on special times of heightened danger to establish a panoptical and decidedly supra-local presence on the rivers.

Nonetheless, these ambitions were certainly in keeping with the Instructions for the Agent. Article 43 of the Instructions enjoined the Agent, in response to dike breaches and flooding, to do everything that he deemed necessary, even in the face of resistance. If necessary he could count on the armed might of the Executive Body. He was to adopt any and all measures that might contribute to closing the breaches and to rapidly draining off the floodwaters so as to minimize damage to nearby places and minimize costs to the inhabitants. ${ }^{24}$ From a legal point of view, the question was no longer whether the national government could claim a commanding

\footnotetext{
22 The dikes along the northern shore of the Lek survived, at least in the imagination of a number of prominent water engineers and the general public, thanks only to a spontaneous breach in the dikes along the opposite, southern shore at the Spoel, just upstream of Culemborg. This "natural" event was seized upon as a precursor for artificial measures (never implemented) to preserve the Northern Lek Dike in both 1803 and 1809. See Welcker.

${ }^{23}$ Quoted in Jan Zacharias Mazel, De verdediging der Rivierdijken bij IJsgang en hoog Opperwater (Leiden: P. Somerwil, 1886), 19. Krayenhoff was a highly capable and well-respected physician, philosopher, military engineer and patriot who is best known for his precise triangulation and elevation mapping of the territory of the Batavian Republic, Belgium and Luxemburg carried out between 1802 and 1811 . Aside from their military relevance, the resulting maps and their underlying measurements were crucial to establishing a uniform national system of measurements and correspondence on the rivers.

${ }^{24}$ Quoted in Jan Zacharias Mazel, De verdediging der Rivierdijken bij IJsgang en hoog Opperwater (Leiden: P. Somerwil, 1886), p. 26.
}

role on the rivers during times of flood and crisis, but rather how far it could go in claiming spaces and times at the expense of local and provincial interests. Would the central state be satisfied with the right of inspection and supervision over local dike boards in times of crisis and with the panoptical accumulation of information on the state of the river in times of flood? Or was this merely an entering wedge for a much more decisive presence in the various spaces on the river in times of flood - and eventually in normal times as well?

The surveyors and engineers heading the new Rijkswaterstaat seem in any case to have had little faith in the competence of the officers of most of the local water boards or in their fortitude in times of danger. One letter complained that "often enough the little knowledge found among some of the officers of the dike boards has required assistance from the state, when it concerned only daily troubles and quite normal losses of land." 25 And as the formidable Christiaan Brunings wryly noted: "that the aforementioned dikeboard needs no advice in times of danger, one must believe on the basis of the testimony of the Departmental (i.e. provincial, cd) Government, on account of the competence of its members; and indeed this dike board seems to have undergone a favorable change because previously such competence concentrated itself chiefly in the person of the dike master." ${ }^{26}$ Such sentiments motivated the newly appointed inspectors-commissars for the river departments to work out a plan for wintertime river surveillance during a meeting held at Vianen on December 12 and 13, 1800. It was agreed that when high water or potential ice jams threatened the river-dikes, the inspectors-commissars would occupy command posts on the rivers and distribute their subordinate personnel at interstitial positions along the dikes. ${ }^{27}$ Correspondence among the posts about the condition of the river and the dikes would be maintained by "hussars or dragoons." Officers and troops garrisoned at towns along the river could be commandeered to lend "necessary assistance" in case of need. A system of signals using coded cannonades and flags was adopted to communicate about specific events or impending dangers - and also as warnings to the inhabitants. It should be noted that this was not a covenant with the water boards but rather more like a plan for "occupation" of the dikes by the central state during times of ice and high water. Such a covenant was in fact considered at the meeting, but it was deemed too late in the season to undertake the necessary negotiations with the numerous dike boards involved. Arrangements were made to "correspond" with water boards and municipalities on the German Middle Rhine in order to be apprised of conditions upstream (washes, the immanent breakup of river ice, and weather conditions) at the earliest possible moment.

\subsection{A delicate balance: 1801-1806}

In October 1801, a new constitution curtailed the powers of the central Representative Assembly and restored to the Departments (roughly equivalent to the erstwhile provinces) many of the powers they had enjoyed prior to 1798 . The Agents were replaced by "councils" charged with carrying out the policies of the Executive

\footnotetext{
${ }^{25}$ Letter Council of Internal Affairs to the State Executive (Staatsbewind) 19 January, 1803, no. 42/10. Cited in Welcker, p. 19.

${ }^{26}$ Report C. Brunings to Council of Internal Affairs, 23 February, 1803. Cited in Welcker. Welcker noted that the dike-board referred to was the Northern Lek-Dike above the Dam, one of the two dike boards responsible for the vulnerable Northern Lek Dike. The dike master was an employee of the dike board - often one of the local farmers - charged with day-to-day management of the dikes. Bruning argued that at least in former times - the only competent person in the water board was the subordinate dike master.

27 This personnel consisted of permanent employees of the Rijkswaterstaat, but also of temporary functionaries recruited from among the local dike masters. So despite the fact that there was no formal arrangement between the Rijkswaterstaat and the local boards, the Rijswaterstaat could avail itself of local knowledge about the river and the dikes.
} 
Committee. One of these, the Council for Internal Affairs, was made temporarily responsible for central water management and flood control, and hence determined policy for the corps of inspectorscommissars (i.e. what would later become the Rijkswaterstaat). However, the situation of this corps had changed dramatically with the restoration of departmental (provincial) powers, in particular the restoration of the right of departments to superintend the local dike and water boards and of their right to levy taxes. It was no longer clear - and the constitution did not alleviate the ambiguity - what role there was for the different bodies of the central state in the management of the rivers and especially in the management of the dikes.

The Rijkswaterstaat, i.e. the corps of commissars-inspectors, found themselves in a political limbo: on the one hand still charged with implementing some sort of "superintendence" of the state's waters and flood defenses, but on the other hand now sundered from direct "correspondence" with the water boards (and their dikes) by the intervening powers of the Departmental Governments. However, the centralist impulse was anything but moribund. $^{28}$ The Constitution of 1798 had clearly made its mark; the Rijkswaterstaat had tasted of the contested fruit of national power and was loath to surrender it again.

In the extremely frigid winter of 1803 , with the rivers frozen over and under the immanent threat of a thaw and consequent ice jams and flooding, the plan to institute a so-called "extraordinary" river correspondence again surfaced. This plan had been floated at the above-mentioned meeting at Vianen in December 1800 , and provided for the inspectors-commissars of the Rijkswaterstaat to take effective command of dike inspection and correspondence supported by the officers and functionaries of the local dike-boards and their dike-armies (and also by government forces garrisoned along the river). It might have been possible, as J.W. Welcker argues, to have arrived at an understanding on the extraordinary river correspondence with the Departmental Governments, and to ensure the cooperation of local dike boards through the formers' (legally sanctioned) intercession. ${ }^{29}$ However, the Council for Internal Affairs, hewing to the social contract of 1798, pursued an authoritarian course, requesting authorization from the Executive Body on January 19th, 1803, to "implement all means and resources as the unhoped for emergency may demand, whether due to the breaking up of ice or high river discharges." 30 The Executive Body acceded and noted that they "expected" the Departmental Governments "to demonstrate all possible cooperation in this matter." ${ }^{31}$

On January 21st the Council for Internal Affairs set forth its instructions for the upcoming "extraordinary correspondence." Once again, Lt. Colonel Krayenhoff was contracted to direct the operation, which included the sole responsibility for directing military operations "as the overcoming of resistance and the good order of the correspondence shall require." 32 The inspectorscommissars were enjoined "in all their actions to conserve as much as possible the mutual understandings with established powers" in order to ensure "a regular and friendly correspondence between themselves and the various Dike Boards." ${ }^{33}$ The instructions included the specification of stations for the inspectors-commissars

\footnotetext{
28 Article 68 of the constitution of 1801 granted "superintendence of all dikes and waterways" to the Departmental Governments, while Article 69 limited national "superintendence" to maintaining navigability of rivers and seaways and mediating between the interests of different Departments." Welcker, p. 36, Roëll.

29 Welcker, p. 24-25.

30 Welcker, p. 25

31 Welcker, p. 26

32 Instructions for River Correspondence, Council of Internal Affairs, 21 January 1803. Appendix 8 in Welcker, p. 177.

33 Instructions for River Correspondence, Council of Internal Affairs, 21 January, 1803. Appendix 8 in Welcker, p. 178.
}

and their assistants, as well as a list of the cavalrymen required to maintain the correspondence up and down the branches of the Rhine and the Meuse. ${ }^{34}$ Finally, the Departmental Governments were requested to "operate as communicatively as possible" with the inspectors-commissars and "further to maintain such mutual correspondence as the interests of the nation in general, and those of the inhabitants of each district in particular may require."35

At the end of January 1803, a threatening thaw set in and by the first week of February inspectors-commissars had assumed their pre-ordained positions, the cavalry had been mobilized and other preparations for the upcoming correspondence were in full swing. However, on February 6th a new period of frost set in and inasmuch as frozen rivers were not a threat, the operation was called off. However, in the meantime the Departmental Governments along the big rivers had received requests to cooperate with the correspondence and to instruct the dike boards under their superintendence to do likewise. They were up in arms and dispatched letters to the Executive Body which began by expressing their appreciation of the present emergency and their pragmatic compliance with the requests of the Council for Internal Affairs. ${ }^{36}$ However, they bitterly condemned as unconstitutional the Council's efforts to circumvent the Departmental Governments in trying to establish a "river correspondence" directly with the dike boards. The dikes belonged to the dike-boards and now, indirectly, only to the Departments. The nation-state no longer had any business on the dikes, except at the behest of the Departments. Adding fuel to this already considerable fire, the Council for Internal Affairs had passed an even sharper resolution on February 2nd, prior to receiving the above-mentioned responses from the Departmental governments. The Council argued that, having as yet received no response from the Departmental Governments to their circular missive of January 21st, they could not therefore in the present threatening circumstances be confident of their cooperative attitude. Hence, they "authorized and, if necessary, commanded" Krayenhoff and the inspectors-commissars "in cases of procrastination or insufficient cooperation by the respective dike boards, to give such orders to the dike boards, and themselves undertake such measures, as the critical circumstances of the Rivers, Dikes, Sluices, etc. might require." 37

This resolution set bad blood all along the rivers. The departmental governments perceived it as unconstitutional interference by the central state in their internal affairs. In their view, the only bodies that could give "orders" to the dike boards under the constitution of 1801 were the departmental governments. The department of Utrecht fulminated that they hardly knew what to think of the articles regulating supervision of water management both in the national constitution and in the constitution of the Department of Utrecht, when "another body (the Council for Internal Affairs, CD), unknown to either of these constitutions, is able, contrary to these articles, to, as it were, insert a kind of authority in between the power entrusted to the Executive Body in general and the Departmental Governments in particular." ${ }^{38}$ The dike boards themselves concurred in condemning the show of force by

\footnotetext{
347 officers, 5 sergeants, 34 corporals and 123 "men" of the light Cavalry were required to maintain the correspondence. In addition the commanding officers of all these regiments were requested to place their troops at the disposition of the commissars-inspectors and to dispatch them to such locations as the commissarsinspectors should designate "as conditions demand." Welcker.

35 Instructions for River Correspondence, Council of Internal Affairs, 21 January, 1803. Appendix 8 in Welcker.

36 They refused to correspond directly with the Council for Internal Affairs because in their opinion they were subordinate only to the Executive Body by the terms of the Constitution of 1801 , and were thereby sovereign powers in regard to water policy in their departments - including of course the superintendence of dike boards. Welcker, p. 34 .

37 Resolution of the Council of Internal Affairs, February 2nd, 1803. Welcker.

38 Letter Department of Utrecht to Executive Body, February 9th, 1803. In Welcker,
} p. 39. 


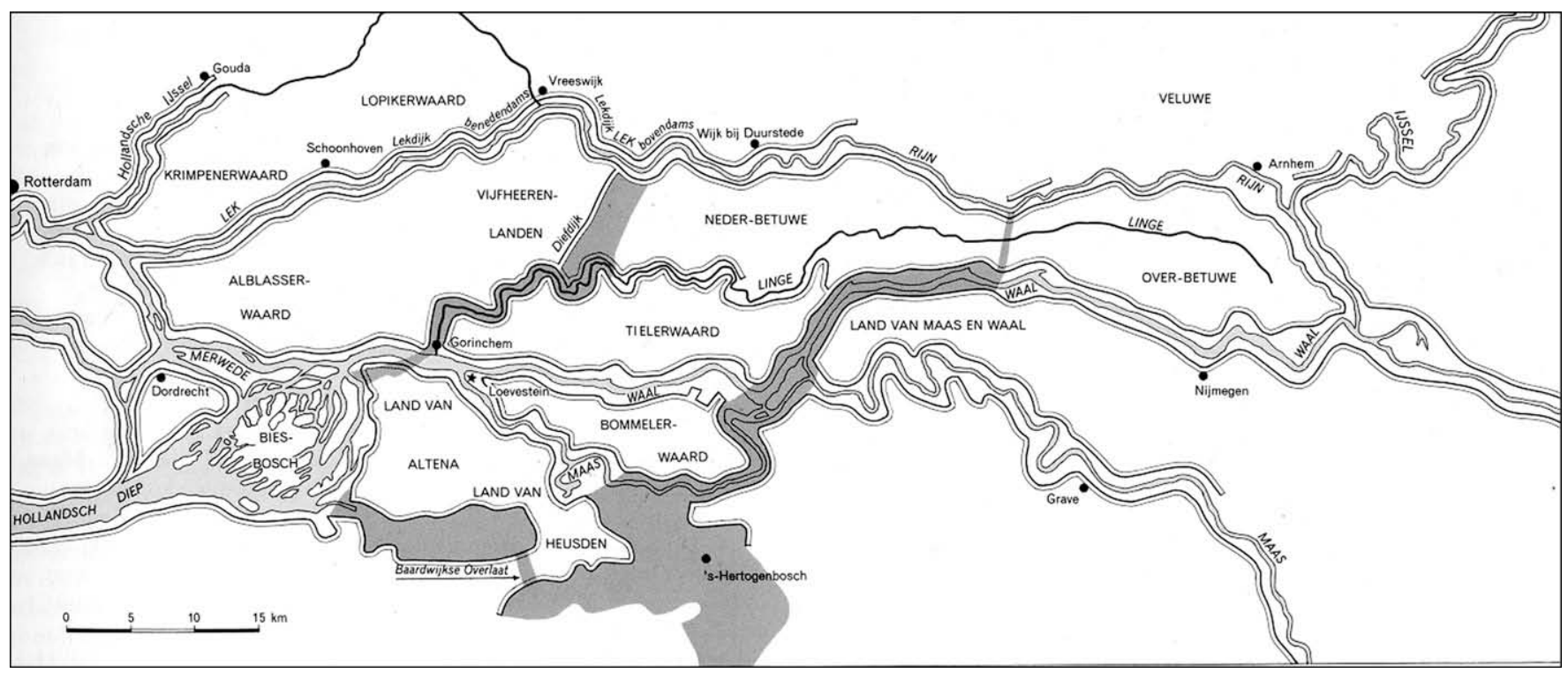

Fig. 2. Rhine and Meuse distributaries in the Netherlands.

the Council of Internal Affairs. The Lek Dike below the Dam notified the Department of Utrecht that they considered the extraordinary correspondence an insult to their competence, and that it was in any case unnecessary because they were quite capable of carrying out a correspondence themselves and had done so frequently in the past without all the consternations and errors of the present military correspondence. Their upstream neighbor, the Lek Dike above the Dam, declared that the present correspondence as organized by the Council for Internal Affairs utterly conflicted with the "organization of the constituent powers as well as with the true interests of the inhabitants", and requested that "the commissars-inspectors be recalled from the dike as soon as possible in order to prevent additional confusion and calamities, and ... be instructed to respect and obey the orders of the Departmental Government, as well as those of the dike-boards ..." 39

Welcker suggests that had the thaw that set in at the end of January continued, matters might yet have been resolved. As it was, the period of inactivity that ensued, plus the rebellion that had broken out among the Departments, gave the Council for Internal Affairs and the Corps of the Rijkswaterstaat an opportunity and cause to develop alternative plans that required authority over a new space on the river, the lands behind the dikes. Under the still impending threat of a thaw, and effectively thrown off the dikes by the violent opposition of the Departments and the dike boards, the Rijkswaterstaat elite forged new plans to prevent a breach of at least the crucial Northern Lek Dike. The inspiration was the "natural" dike breach in the Southern Lek Dike at the Spoel, just upstream of Culemborg and the so-called Dief Dike, that occurred during the flooding in 1795 , see Fig. 2. Many experts, including Jan Blanken and Christiaan Brunings, were convinced that this breach and the floodwaters that poured through it into the low-lying Neder-Betuwe polder saved the Northern Lek Dike and with it the provinces of Holland and much of Utrecht from severe and rapid inundation. The upshot was a new plan to artificially breach the Southern Lek Dike at the site of the old 1795 breach if during the coming thaw the Northern Lek Dike seemed at the point of rupture. Of course, it would also inundate the lands behind the Southern Lek Dike east

\footnotetext{
39 Letter Lekdijk Bovendams to Departmental Government Utrecht, February 3rd, 1803. Quoted in Welcker, p. 43.
}

of the Dief Dike (the Betuwe and Tielerwaard), and cause a great deal of suffering and damage there. But to the national government and its engineers, preserving Holland and Utrecht was obviously more important.

In terms of the relative areas of inundation, this may have been justified, but there was a serious constitutional (and moral) question here. Could the nation-state sacrifice the lands and goods, and even threaten the lives, of a part of its population in order to preserve another part? Such behavior was accepted as an unfortunate prerogative of God or Nature, but hardly of republican governments. "Only an unswerving conviction that this was the only possible escape from inevitable doom and a bizarre sense of its own power could have moved the Executive Body to make this decision. That it was unlawful and unconstitutional is beyond all doubt." 40 It was clear in any case that the state's new strategy of extending its sovereignty to the private and public spaces behind the dikes - having been denied access to the dikes themselves was not going to improve relations with either the Departmental Governments or the dike-boards whose dikes were to be breached and whose lands were to be flooded. ${ }^{41}$ The Council for Internal Affairs was well aware of this and decided on February 15th that,

\footnotetext{
40 Welcker, p. 54.

41 In fact the plan included not only the proposed floodway from the Southern Lek Dike through the Neder-Betuwe, but two other floodways as well, one called the Lijmers which would drain water from the Pannerdens Canal into the Geldersche IJssel and another which would drain excess Lek water through the Geldersche Vallei. All the proposed floodways had the single purpose of either keeping water out of the Nederrijn-Lek, or of draining it off to other bodies of water if it got too high. The proposed floodway through the Neder-Betuwe was the most contentious, because of the relatively dense population and the prosperity of the farms. The idea of floodways and river-diversions was by no means new, of course. In their natural state the rivers had always tended to overflow their banks and to create multiple beddings in times of flood. Some of these were incorporated into the rivers after they were diked by creating lower sills along certain stretches of dike which would allow the river to overflow into the contiguous polders, to rejoin it at a point tens of kilometers further downstream. Due to floodways and low sills along the Meuse dikes, a good deal of the province of Noord-Brabant was thus frequently flooded during the winter. It should be noted that the plan to breach the Southern Lek Dike would have much more impact than a regulated floodway at the same location. For one thing the breach would be instantaneous, and immediately inundate the countryside to the full height of the flooded river. For another thing the lack of a proper floodway with guide levees would result in indiscriminate flooding of the countryside. In later years, there were in fact proposals to institutionalize a floodway through the Neder-Betuwe which would have caused a lot less damage.
} 


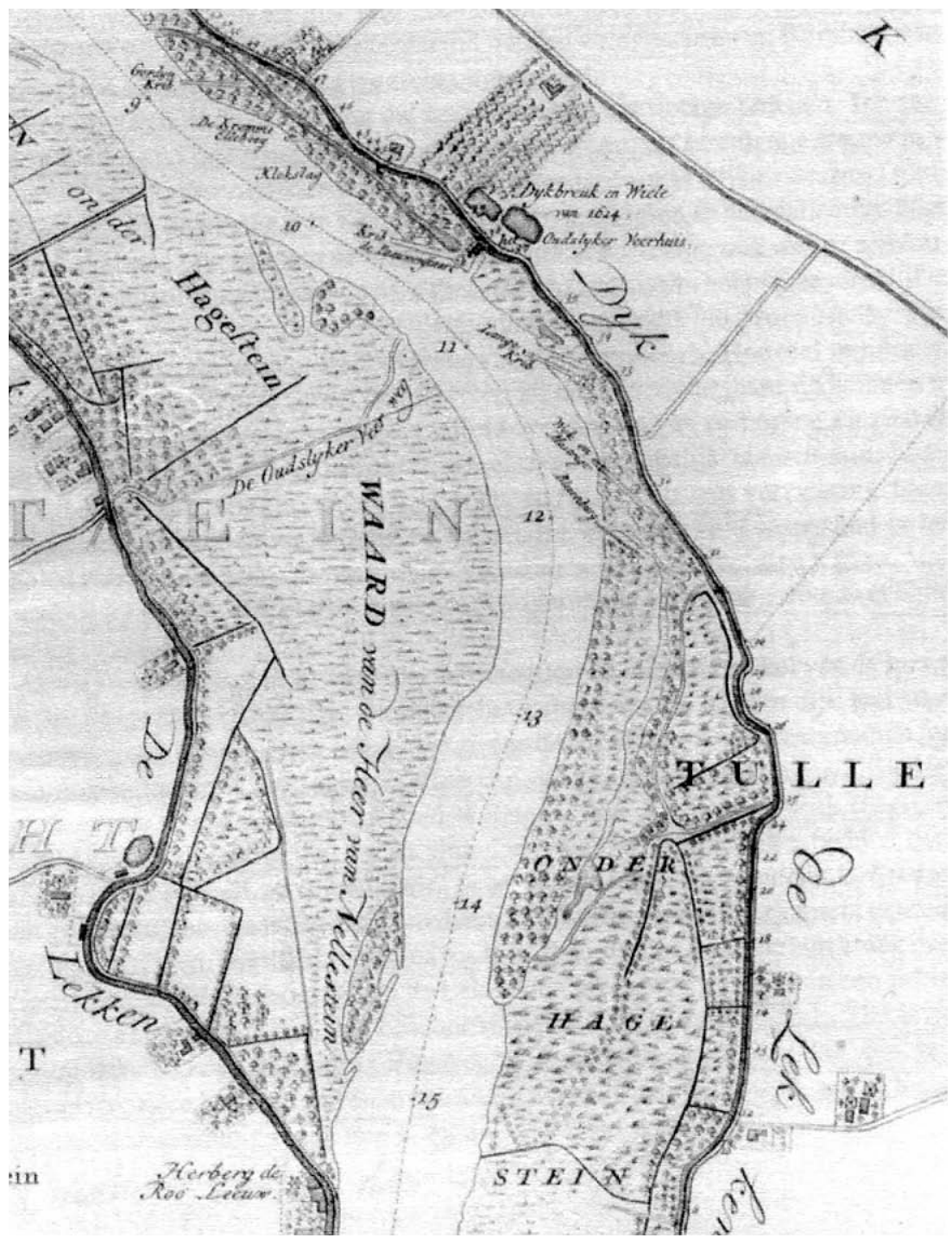

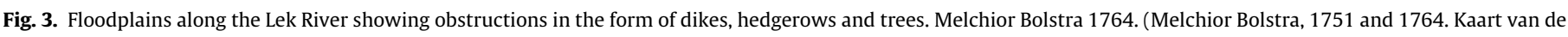

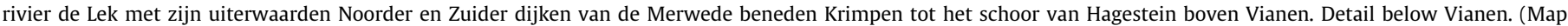
collection hoogheemraadschap van Rijnland nr 59, blad 7)).

rather than stir up a hornet's nest, it would be better to keep the preparations secret. ${ }^{42}$ In order to ensure the success of the plans even in the event of violent resistance, two companies of infantry were to be posted at Gorinchem.

The plot was hatched none too soon, because on February 13th it had begun to thaw again, and the breaking up of ice on the river threatened disaster. The commissars-inspector, including Jan Blanken who had masterminded the plan and was to lead the operation on the southern shore, returned to their posts on the rivers. Blanken studied the situation on the Southern Lek Dike, arranged for both open and sealed instructions for two trustworthy dike-masters and for secret signals that would announce the operation's inception from the northern shore Lek town of Vreeswijk. He also prepared orders for the infantry troops stationed in Gorin-

\footnotetext{
42 However, the original decision of the 14 th included a provision to inform the Departmental Governments of the impending plans, and to invite them to send delegates to The Hague to discuss objections. The affected departmental governments hastened to do so, and protested in no uncertain terms. Although the Departments were thus aware of the general tenor of the plans, they did not know how or when they were to be carried out, because of the secrecy surrounding the preparations
}

chem. ${ }^{43}$ The dike masters were charged by the open instructions to wait for the secret signal from Vreeswijk and only then to open their secret instructions. ${ }^{44}$ These charged them to take 300 men from the "dike armies" of the southern-shore polders of Alblasserwaard and the Vijfheerenlanden (which were in the Department of Holland and would not be affected by the breach because they were behind the Dief Dike) and proceed to cut the Lek Dike at the appointed location. From a pre-1795 perspective, this would have looked very much like an invasion by foreign troops. ${ }^{45}$

\footnotetext{
43 These instructions stipulated that the troops should be "well armed" and "supplied with sufficient live ammunition", and that they should be prepared to "turn violence with violence" in order to protect the dike workers in the execution of their tasks. Instructions Jan Blanken to the Commanding Officer of the Garrison at Gorinchem, February, 1803. Welcker, p. 66.

44 The dike masters, in other words, were unaware of the nature of their task until its prosecution was immanent.

45 The dike that was to be breached and the lands that were to be flooded were in the Department of Gelderland. Holland started just downstream on the other side of the Diefdijk and Utrecht occupied the opposite (north) shore.
} 
In the event, forceful protests in The Hague from the Departmental Governments, especially that of Gelderland whose lands were being threatened by inundation, as well as studied reluctance by Krayenhoff and Brunings, stationed on the northern shore and charged with giving the secret signal for cutting the southern dike, to actually do so, even when the river had risen to the very top of the northern dike, made all these preparations futile. Of interest is the prophetic wording of objections to the plan by delegates of the Department of Gelderland. With considerable ardor they condemned the "measures to be taken as contrary to the spirit of the Constitution and the Departmental Regulations, irreconcilable with a Republican polity and only tolerable in a monarchical and despotic state." 46

That monarchical and somewhat despotic state would come soon enough, but for the moment the crisis of 1803 had passed as the ice was carried away and river levels returned to normal. But the entire affair had discredited the administration of the rivers and especially the management of floods by the Council for Internal Affairs. By October, responsibility for the national Waterstaat had devolved on a new Commission of Superintendence for the Rivers, which had been mandated by the Constitution of 1801 but never implemented. The rights and duties of this commission and its relationships to the Departmental Governments and the dike boards were spelled out in its charter. They reinforced the political mapping of spaces and times on the rivers as set out in the 1801 constitution, and made short shrift of the ambiguities that had caused tempers to rise in 1803 . While in principle enabling the nation-state to deal with the rivers, especially in times of danger, as a kind of national commons, they also contained express guarantees of autonomy for the Departments and the dike boards over their internal affairs. This new arrangement made it possible for the Executive Body to promulgate two new laws, both of which survived through the remaining political changes of the "French Period" and its demise, and both of which ultimately became keystones of river policy under the Kingdom of the Netherlands.

The first was a law regulating "extraordinary river correspondence," passed January 10, 1806. These regulations contained detailed instructions for the routing of messages between watchposts, but were tellingly silent on the division of authority among the inspectors of the Rijkswaterstaat, the Departmental governments, and the officers of the dike boards. It stands to reason that the Rijkswaterstaat, with its cosmopolitan expertise and monopoly on information was the tacit master of the situation, but it was apparently left to the diplomacy of the Inspectors and their staff to implement this mastery in practice. Nonetheless, a legal framework for an "extraordinary river correspondence" had been laid down which in times of danger encapsulated the traditional local "dike watches" and the supervision thereof by the Departments within a national panoptical regime of surveillance. In subsequent years, this law and the practices it defined would be further refined.

The second law extended the influence of the nation-state to the riverbed itself and the floodplains. This would ultimately prove at least as fruitful as the establishment of multi-level "correspondence" in times of danger. The law in question, passed by the Executive Body on February 24th, 1806, was the "General River and Water Law over the Rivers and Streams of this Republic." The law represented an effort to improve the quality of the winterbeds (floodplains) of the rivers as conduits for water and ice. Its aim was thus to prevent or at least reduce high river stages and the formation of ice dams, rather than to deal with their consequences, as

\footnotetext{
${ }^{46}$ Minutes of the meeting of the Council of Internal Affairs with representatives of the Departments, February 22, 1803. Appendix 54 of Welcker.
}

was the case with plans for river correspondence and artificial diversions. The law set limits to the rights of riparian landholders to reclaim land from the riverbed. Hence, excepting explicit permission from the Commission of Superintence, it prohibited the construction of new dams or other works, and the lengthening or heightening of existing works, in order to speed up sedimentation of new land. It also prohibited salmon nets or other works that would interfere with the river's even flow. These prohibitions applied both to private individuals and to corporate bodies (like the dike-boards and Departmental Governments). In like fashion, "emerging" land could not be built up and privately claimed if this "compromised the general interests of the country." As far as the floodplains were concerned, the law stipulated that all buildings and works deemed disadvantageous to rivers and streams were to be removed, and that it was henceforth unlawful to build or heighten summer dikes without express permission from the Commission. Also, trees could not be planted on currently unplanted portions of the floodplains. Furthermore, owners of riparian lands could be compelled by the state to construct such works (e.g. groynes and wing-dams) as the state deemed necessary in order to improve the river. ${ }^{47}$ Article 10 , finally, represented a diplomatic effort by the national government to achieve a measure of standardized control over the quality and construction of the dikes themselves. It outlined a procedure whereby the Commission of Superintendence, judging that a particular dike needed "heightening, strengthening or improvement" or that particular summer dikes or dams under the care of a dike-board be removed, could approach the Departmental Government responsible for the "superintendence" of the dike-board in question to "order" that dike-board to comply with the wishes of the Commission. Clearly this was a roundabout solution which respected the Departmental Governments' constitutional autonomy in these matters - a far cry from previous efforts at instituting river correspondence, let alone occasional plots to breach dikes. Nonetheless - at least with the wisdom of hindsight - this article, and indeed the law as a whole, turned out to be a major step toward a practical conception of the rivers as a unified drainage system, indeed of viewing them as national commons, the use and abuse of which had to be regulated by the state as defender of the collective good and bulwark against chronic tragedy.

\subsection{The Bonapartist State: $1806-1814$}

On June 5th, 1806, the Emperor Napoleon Bonaparte crowned his brother, Louis Napoleon, King of the Netherlands. The administration of the Waterstaat was once again reshuffled in order to fit it into the new autocratic political structure. King Louis Bonaparte, like the Patriots before him, had the good sense to respect existing local arrangements for drainage and the maintenance and defense of the dikes, but clearly the advocates of a more centralist and authoritarian approach to spaces and times on the rivers had little reason to be dissatisfied with his accession to the throne. While the king's first Dutch winters had been mild and uneventful, at the end of December 1808, it began freezing hard during a period of high water, and the rivers froze from shore to shore. In this time of trepidation, the words of the Departmental Deputy of Gelderland about the ruthlessness of "monarchical" and "despotic" states proved prophetic. It was the King's considered opinion, and therefore policy, that if it were possible to save the Northern Lek Dike by sabotaging the Southern one, it should be done. The King himself

\footnotetext{
47 If the owner complied, then the newly formed land could be claimed by the owner. If the owner refused and the state built the necessary works, new land would fall to the state. This created a possibility for the state to expand its territorial hold on the rivers at the expense of private citizens. This, however, could in no way impair the duties of the responsible dike boards to maintain their dikes and to protect them with river works at their own costs according to their own laws and regulations.
} 
reasoned that it made sense, "by flooding a small part, to preserve a more extensive and costly tract of land from flooding." Clearly, an absolute monarch, being in a sense uncontested "owner" of all the riverine and riparian spaces, could make decisions that republicans could not. In any case, Blanken was ordered to take exactly the same measures (including his secret instructions) as he had in 1803 and, in the end, with the same outcome. Unluckily for Holland's peace of mind, a dike along the northern shore of the Waal breached and flooded the Betuwe so that it could no longer receive the waters of the Lek, even were the southern Lek Dike to be pierced. As it turned out the Northern Lek Dike withstood the onslaught - carefully tended under the regime of the "extraordinary river correspondence."

The "failure" of the emergency derivation through the Southern Lek Dike in January 1809 by no means marked the end of this rather draconic project. Only a year later, on January 25th, 1810, Blanken submitted a Mémoire to the King outlining improved plans for carrying it out. One of the weak spots, in Blanken's opinion, was entrusting the decision to breach or not to breach to one or two individuals, whom he felt could not bear the responsibility, and hence would tarry needlessly and perhaps fatally in ordering the signal to be given. He therefore proposed a committee composed of the Minister of Waterstaat or a direct representative, the inspector at Vreeswijk, the President and one or two officers of the dikeboard of the Northern Lek Dike above the dam, and finally one or two of the oldest and most experienced of the dike-masters from the same dike board. The decision was to be taken by majority vote and to be "final." This was of course a preposterous proposal, which would place the fate of the Southern Lek Dike during times of flood in the hands of those who would most directly profit by its destruction - and by the ruin of their neighbors to the south. ${ }^{48}$

In July 1810, the emperor Napoleon Bonaparte recalled King Louis and simply absorbed the Netherlands into his empire, which by then also included the entire German Rhineland. The Rijkswaterstaat became a subdivision of the French Service des Ponts et Chaussées. While this compelled all the inspectors and engineers to write in French, it certainly did not dampen their ardor for increasing the national grasp on riverine spaces nor diminish the possibilities for doing so. Blanken's Mémoire, wherein he finally gave free rein to the panoptical and authoritarian ambitions that had motivated him and his colleagues during the crisis of 1803 and again during the flood of January 1809, is a case in point. Blanken, who had remained inspector general of the Rijkswaterstaat, used the Memoire to fill in the gaps in the general instructions of 1806 and 1808 , and also to define the responsibilities of the various parties. State engineers were beholden to follow without hesitation the orders of the inspector-general, and had to submit daily reports as well as a final report at the termination of the correspondence. The dike boards too had to submit reports to the inspector-general. In addition, if any of the state engineers requested the performance of some urgent task, by well-motivated letter, the "dike boards had to acquiesce with alacrity and with all the credit, funds and care over which they disposed, and eschewing efforts to delay the execution of these tasks by expressing doubts or requesting convocations." 49 Blanken clearly was a man of great practical experience in dealing with recalcitrant dike boards. He concluded the final section

\footnotetext{
48 Welcker, though his animosity toward Blanken is sometimes excessive, is right in condemning this proposal as "dishonoring Blanken, who made it possible for good men to be seduced into committing evil deeds, against their wishes and as it were unknownst to themselves. It was a reckless gamble to so severely try human steadfastness..." Welcker, 139. In the event Blanken's committee was never instituted, nor indeed was the Southern Lek Dike ever sabotaged. However, the notion of a derivation through the Betuwe - as well as in many other places continued to be considered a palliative for threatened dikes until well into the 20th century.

49 Mazel, p. 67
}

of his Mèmoire with a note on his pet subject. He recommended that 200 infantry troops be posted at Gorinchem in order to deal with violent resistance by local inhabitants against efforts to artificially breach the dikes. Blanken's Mèmoire proved to be the basis for the definitive structure of the "river correspondence," as it crystallized out in the course of the 19th century. ${ }^{50}$ It defined both the normal correspondence maintained by the dike boards and "extraordinary" correspondence maintained by the state. During times of danger, this "extraordinary" correspondence effectively entangled the entire river system and its local defenders within a single web of information and control managed by the corps of the Rijkswaterstaat.

\section{Conclusion}

The chequered history of the integration of a national level of water management and flood control into the robust provincial and local arrangements prevailing in the Netherlands obviously did not stop in 1812 or 1814 . With the fall of Napoleon and the establishment of the Kingdom of the Netherlands in 1815, a new political situation arose: on the one hand restoration of the provinces in something like their former glory, but on the other hand the (re-) emergence of a strongly centralized, indeed autocratic nation-state. In this polarized force-field, a national level of river management continued to develop, over the systematic opposition of the provinces and the ressentiment of the water boards to be sure, but nonetheless vigorously pursued by a small coterie of engineers and surveyors who harbored the "modernist" conviction that centralization, rationalization and superior knowledge offered the best hope of managing floods on the rivers.

As had been the case during the Dutch Republic, the Batavian Republic and the "French Period," the local water and dike boards stood at the epicenter of Dutch water management. Armed with their own charters, laws, and budgets they were responsible in the first place for building and maintaining works to "turn the water, or show it the way out." 51 The provinces "superintended" the work of the water and dike boards while the Rijkswaterstaat "superintended" works of national importance and in particular the rivers according to the Law of February 24th, 1806, and the regulations for "extraordinary river correspondence." The question was what the state would do with these prerogatives, especially in view of the annual threat of flooding from ice-choked rivers in flood.

During the French period two types of "national" approaches had crystallized out. Both were based on a privileged panoptical view of the rivers, such as neither the provinces nor the dike boards were capable of achieving. To be sure, this was seriously hampered by the lack of a good and detailed survey of the rivers, but this would be made good by the Rijkswaterstaat in the $1820 \mathrm{~s}$ and 30s. ${ }^{52}$ Nonetheless, the Rijkswaterstaat's perspective was inherently panoptical and national, and it was hence the only actor capa-

\footnotetext{
50 It was the textual inspiration for a new Regulation for River Correspondence, enacted in January 1812 and revised under rather different political circumstances in 1835. Mazel, p. 70

51 The turn of phrase is by the first executive board of the Dutch Royal Institute of Engineers, in their foreword to the Institute's first volume of Transactions, 1848, First Part.

52 Indeed, the lack of up-to-date detailed maps made the River Law of 1806 as well as a Dike Law passed in 1810, almost dead letters. The Dike Law had created "Dike Rings" by merging polders protected by a ring of major primary dikes. The idea was to replace maintenance duties for the dikes in natura by taxes, and so to make it possible to include those living at great distances from primary dikes, but nonetheless protected by them, to contribute to their upkeep. This arrangement was long-resisted, despite its manifest justice, and has only been effectuated in recent years. For the history of hydraulic measurement and map-making in the Netherlands, see H.C. Toussaint, "Uitgetekend en uitgemeten. De Algemene Dienst van Rijkswaterstaat," Tijdschrift voor Waterstaatsgeschiedenis 7, no. 2 (1998), Toussaint, Uitgemeten en uitgetekend: de geschiedenis van de Algemene Dienst van de Rijkswaterstaat'sGravenhage, 1998.
} 
ble of pursuing policies that optimized the situation for what was called "the good of the nation." What were the two strategies it pursued?

\subsection{Flood control}

The first strategy, about which much has been said above, was based on preventing actual dike-breaches during times of high water. It had two variants. The first entailed ensuring that the dikes were well scrutinized, that everyone and everything was prepared to intervene when dike-failure threatened, and that information about the state of the flood along the entire river be accumulated at a central decision-making point. The second entailed making or activating floodways and derivations to draw water off the rivers and onto the surrounding countryside, thus relieving pressure on the dikes and preventing accidental and unpredictable catastrophic dike breaches. The Beerse Floodway along the Meuse had functioned like this for centuries. Although at various times plans were made for many more floodways, in practice few were realized, and then chiefly along the Meuse. The floodways had all been abandoned by the time the Beerse Floodway was closed in 1942.

This "flood management" approach was based on the nationstate's authoritative mastery over extraordinary times on the river. ${ }^{53}$ During these extraordinary times the national Rijkswaterstaat was allowed far greater prerogatives on and around the dikes than during normal times. The provinces looked the other way while the state engineers exercised authority over the dike boards and their "dike-armies." Due to their system of horse-borne (and of course later telegraphic) correspondence, the state engineers were apprised of conditions at all points on the river, and could hence make more "intelligent" decisions - at least from a "cosmopolitan" perspective - in any given local situation than could the local dike boards themselves. ${ }^{54}$ Whether they appreciated this "higher wisdom" or not, the dike boards were beholden to go along with the tactical decisions that it inspired. On the other hand, no one knew the dikes like those who built and maintained them with their own hands, and the local knowledge of inhabitants and dike-masters often proved of great value to the state engineers as they labored to keep the river within the dikes and to apply scarce resources where they were most needed.

The other strategy of "flood management" we have considered is that of derivations and floodways. These could be designed beforehand: for example, by constructing a short section of dike at a lower threshold so that the river would overflow at predictable locations and along defined floodways rather than break through at some random weak spot in the dikes and wreak sudden havoc on the countryside behind. Such sites could also be fitted with special sluices, which made this type of "flood management" more flexible. The crudest variant of this strategy is of course the one we have discussed: that of cutting artificial dike breaches at the moment supreme in order to reduce pressure on neighboring dikes, e.g. the plans for sabotaging the Southern Lek Dike. In both cases, the interest of the inhabitants in keeping their dike whole and their

\footnotetext{
53 Flood-management as practiced by Rijkswaterstaat increased pressure to develop new forms of (panoptical) knowledge like detailed maps and insight into the formation of ice dams, the extent and duration of floods, river depths, etc. In order to carry out the necessary programs of measurement and map-making, a seperate "General Service" (Algemene Dienst) was added to the Rijkswaterstaat in 1809. For flood control and the General Service, see Toussaint, Uitgemeten en uitgetekend: de geschiedenis van de Algemene Dienst van de Rijkswaterstaat. and Bosch, Om de macht over het water. De nationale waterstaatsdienst tussen staat en samenleving 1798-1849, pp. 87-88.

54 i.e. "intelligent" from the Godlike perspective of the least harm for the greatest number. This was not always the same as "intelligent" from the perspective of local interests.
}

lands dry was sacrificed to "higher" or at least "other" interests: i.e. other dikes, lands, provinces. Here too extraordinary prerogatives to pierce dikes were granted to the Rijkswaterstaat as the agent of a purported "national" interest. Although, during the Batavian and "French" period, designs on the Southern Lek Dike were regarded even by the designated perpetrators as more or less illicit operations to be carried out in the greatest secrecy, the very same floodway, albeit in a more manageable and better contained form, and provided with artificial hills to which the population and their cattle could flee, was still being openly recommended as sound policy by a State Commission in 1821 .

The time of ice and flood, the "full river," can be seen, as I noted earlier, as a kind of temporary commons. It is a commons of shared risk, rather than the classic commons of shared resources, but the dynamics and the potential for tragedy are similar. Prior to 1798 , times of "full river" threw all the dike boards back on their own limited resources and their partial knowledge of the situation. This willy-nilly involved them in a strategic game of blind and collective "processing" of excess river water. Local responses to the full river were framed in relative ignorance of what was happening elsewhere on the river and, particularly, in ignorance of what was approaching from upriver. The "full river" pitted each dike, each polder and each province against its counterpart. Every dike breach somewhere else was a boon that lessened the chance of local dike failure. Ice dams that could be broken up could happily become someone else's problem if they consolidated again far enough downstream. Every upstream floodway that went into action drew water off, and was seen as improving local chances of surviving the "full river." The most brutal feature of this unregulated "risk commons" was that it provided everyone with an incentive not only to make their own flood defenses as invincible as possible, but also to weaken those of others - up to and including the cutting of dikes by stealth and deceit. As long as the dikes themselves were inviolable commons owned and managed by dike boards representing the collective will of the landowners of riparian polders, nothing could alter this situation. Though the dike boards themselves prevented tragic outcomes at a local level, e.g. by combatting "free riding" in the construction and maintenance of the local dikes, they themselves had no other choice than to be selfish and amoral actors in the tragedy-bound "risk commons" of the "full river."

From the panoptical view of the nation-state, the self-centered strategies of the individual dike boards and their supervisory provinces were the ingredients for at best suboptimal outcomes and at worst a full-fledged tragedy of the commons. However, whether the nation-state could improve matters by temporarily taking over the dikes and redefining the "full river" as a temporarily nationalized "risk commons" depended on what aims it pursued and what disciplines it imposed. Its cosmopolitan interests of course differed from those of many of the local riparian populations, and its politicians and bureaucrats could well favor particular regions or social classes over others.

The "extraordinary river correspondence" whereby authority over dike-watches all along the rivers was effectively ceded to the state - though of course only temporarily and according to strict protocol - was a measure which apparently improved everyone's chances to survive the "full river." The superior expertise of the state engineers, their panoptical system of correspondence which provided them with real-time data on the progress of the flood and ice jams, and their ability to concentrate superior forces at threatened locations made it profitable for dike boards to cooperate and transform the "correspondence" into a cornerstone of national river policy. The "correspondence" also prevented the "risk commons" from degenerating into a destructive free-for-all, by reducing the threat that dike-boards or groups of landowners might take matters into their own hands and sabotage some neighboring dike to save their own. 
But the state could easily pursue sectarian ambitions thanks to the temporary toehold on the dikes granted them by virtue of the "correspondence," as, for example, the covert 1803 and 1809 plans for sabotaging the Southern Lek Dike seem to show. In point of fact, by including the sabotaging of dikes in its flood control policies, the state was effectively claiming temporary hegemony over another space on the river: the private and public lands behind the dikes, a claim which appeared to be quite unconstitutional. The more fundamental question here was whether the "national interest" also included the interest of the Betuwe farmers whose homes and farms would be washed away in order to save prosperous, urbanized and extensive Holland. It was of course argued that this was a smaller sacrifice for a greater good, but this would at the very least require absolute certainty about the efficacy of the measure - something about which there really was no consensus.

The same goes for the entire strategy of deviations and floodways. Quite aside from the question of the rights of those whose lands and farms would be deluged, the efficacy of deviations for lowering water levels was seriously debated throughout the 19th century. In fact it was argued that in the long run deviations would ruin the river's ability to discharge water and ice because they would reduce currents, increase shoaling and degrade the river channel both for shipping and for drainage.

\subsection{River management}

This brings us squarely to the second basic approach, about which little has been said above, but which was certainly implicit in the River Law of 1806. It depended on achieving hegemony over the entire riverbed between the mainline winter dikes and prohibiting private or public proprietors from undertaking construction or other activities that would compromise the river's ability to discharge water. This hegemony over the entire winterbed also ultimately provided the legitimation for state reconstruction of the rivers aimed at creating self-sustaining shipping channels and at providing adequate discharge capacity: the large river normalization projects that were carried out after 1850 .

As early as 1804, Christiaan Brunings, though no enemy of deviations, had also made an appeal for the improvement of the riverbeds. ${ }^{55}$ As an exponent of the small coterie of "enlightened" 18 th century philosophers and scientists who had advocated rational and centralized management of the rivers, he argued that all rivers with a light gradient will deterioriate of their own accord unless one fights this evil "by ceaseless, unified measures tending toward a single end." This appeal in a report to the Commission of Superintendence was the beginning of a long and verbose debate on possible remedies for the sorry state of the rivers, carried on in numerous pamphlets as well as in the reports of several full-fledged "River Commissions." But in the short term it also facilitated the General River Law of 1806, which provided the state with legal instruments to prevent further abuse of the rivers' hydraulic capacity by riparian property holders. While the state's hegemony over the river's "summer bed" itself had never been in question, its hegemony over the distinct space of the flood plains and over lands reclaimed from the riverbed certainly was. The Law of 1806 essentially redefined the floodplains as part of the riverbed and hence as state-managed public property, rather than as private property at the disposition of landholders. Thenceforth, private property in the floodplains was subject to state-enforced regulations protecting the general interest in the rivers' ability to drain off water and ice.

The well-known large projects undertaken after 1850 to untangle the rivers, normalize them, and provide them with new mouths on the principle that each river should be able to discharge its own burden of water and ice at all times were direct descendants of Brunings' plea and the 1806 law. Though the river improvements ultimately reduced the frequency and height of threatening high waters, they never eliminated the need for extra vigilance duiring times of danger. And they would have been unimaginable in the first place had the state not been able to employ times of danger to legitimize the imposition of central state coordination and authority on fragmented local regimes for flood control.

\footnotetext{
$\overline{55}$ Christiaan Brunings, Consideratieën nopens de algemeene verbetering der Hoofdrivieren (n.p.: 1804).
} 